\title{
THE MAKING OF A BEWITCHMENT NARRATIVE
}

\author{
Ágnes Hesz
}

\begin{abstract}
By analysing the formation of one bewitchment narrative, the paper argues that narratives on bewitchment primarily serve as communicative devices by which one can negotiate his social position in the community, even in cases when overt social conflict is not involved. In case of misfortune the local bewitchment theories give rise to several competing interpretations in the community (a Hungarian village in Romania). The different versions also assign different roles to the bewitched: some put them into the position of the guilty while others show them as wholly innocent victims. By following the interpretational strategies applied during the construction of the bewitchment narrative of a family whose social position was shaken, the paper aims to show how the bewitched managed to reach a version which has put them into a favourable position, and how this narrative was employed to 'save their faces'.
\end{abstract}

Key words: bewitchment, curse, discourse, Eastern Christianity, narrative Romania, witchcraft

Most of the anthropological, socio-historical and folkloristic studies of witchcraft see the essence of the institution in its function to express and channel existing social tensions by interpreting them as pretexts for certain misfortunes. While this is evidently true for certain periods, communities and cases, the few anthropological studies on contemporary rural witchcraft show that the importance of witchcraft may lie elsewhere than in manifesting social conflicts.

The first to challenge the absolute validity of this interpretation was Jeanne Favret-Saada, who in her thorough study on contemporary witchcraft in France (Favret-Saada 1980) argued that in reality witchcraft accusations were mostly targeted at people engaged in a rather neutral affair with the victims (neighbours), instead of being aimed at those with whom the bewitched had tense relationships (relatives). In her view, witchcraft was to be considered a special language constituting a discourse which, putting otherwise unexplainable events to a certain perspective, offered the bewitched an explanation and solution to their problems. During her fieldwork, and in her analysis as well, J. FavretSaada decidedly took the perspective of the bewitched ${ }^{1}$ and concentrated on bewitchment narratives as "inner" explanations - explanations that the be- 
witched could accept as valid - which inevitably left silent the version shared by the accused party. Moreover, due to the thick veil of secrecy surrounding witchcraft in the Bocage, practically nothing is revealed about the reception of these narratives by the community. Fieldwork experiences from other areas have hinted, however, that the different narrative versions about a single bewitchment case play an important communicative role in the community (e.g., Dionisopoulos-Mass 1976; cf. Blécourt 1999: 207-208). That is, they not only act as psychological and - if counter-magic is practiced - instrumental consolation for the bewitched, but also as an interpretation offered to the public. In cases that are traced back to real social conflicts and involve open accusation, the antagonistic parties use their versions to convince the community of their truth in the conflict, while in cases without a named enemy, bewitchment narratives might serve to win the sympathy of the others. In either case, bewitchment narratives are applied to manipulate public opinion.

By analysing the construction of the bewitchment narrative of one peasant family living in a Hungarian village in Romania, ${ }^{2}$ I would like to further argue that bewitchment narratives - besides their obvious psychological effects - are used as communicative means for negotiating one's position in social space. Although cases burdened with more social conflict might have shown the clash of competing interpretations emerging in the community better, I chose this case because I was closely involved in the last phase of narrative construction. My other reason in doing so was that this case, lacking any serious accusations, served as a further proof that existing social animosity is not an inevitable component for witchcraft to work, and that the gist of the institution lies in its role in communication.

\section{THE CONCEPTUAL FRAMEWORK - LOCAL BEWITCHMENT THEORIES}

Although there are researchers who claim that there is enough ground to suppose that some magical practices classified under the notion of witchcraft sometimes have indeed been carried out in reality, ${ }^{3}$ most cases of bewitchment are only manifested in different types of narratives. This does not only mean that for the researcher they are only accessible through narratives, but that they in fact exist in narratives - or, to be more precise, in the discourse these narratives are part of. In other words, people are bewitched when they, being subject to certain situations, are diagnosed to be so either by an expert of unwitching, or by the community itself.

Formations of narratives on bewitchment are bounded by the conceptual framework provided by local witchcraft theories. In the studied area, which, 
with a pseudonym I will shortly call the Valley, the local concepts on witcheraft show a more complex picture than the so-called suspicion-/accusation-centred witchcraft we know from Western and Central European witchcraft trials and 19th- and 20th-century folk narratives. ${ }^{4}$ In the Valley bewitchment, magical harm done to another person or a group of people, is supposed to be done in basically two ways: either by individual cursing and curse masses paid to the Orthodox priests, or by the bewitching activity of a witch. In her article on the present-day witchcraft theories of two villages in the Felcsík basin, Transylvania, Éva Pócs has termed bewitchment done through the Orthodox priest as grievance-/justice-centred or "religious" witchcraft as opposed to the suspicion/accusation type (Pócs $2001 \& 2002$ ). Both bewitching through the priest and through a witch was present in the community described by her as well, ${ }^{5}$ but the dominance of the two types, however, differs considerably in the two territories. In Felcsík, most bewitchment cases belong to the grievance/justice type, while in the Valley the presence of the two models is more balanced.

In the Valley, the two forms of bewitchment types form an antagonistic pair on the basis of their ideology and function. In the religious, grievance-/justicecentred type the act of bewitchment is performed by an official religious specialist, and the applied techniques - cursing or votive masses, and fasting as a complementary method - are part of the official liturgy of the Orthodox Church. As its name indicates, the main motive to pay cursing masses is to take justice for former grievances by asking God to punish one's enemies. The most frequent conflicts that lead to this type of retaliation are of material nature (disputes about landownership or inheritance, theft, fraud), but marital problems, unrequited love, or attacks against one's reputation may also serve as sufficient grounds. The involvement of God, however, turns the whole act into an ordeal induced by human agents. This means that only the guilty could be punished in this way, and if the curse is directed at an innocent party, the harm unleashed by it will fall on those who have initiated it. Thus, paying cursing masses to the Orthodox Church is a highly risky affair, and only those dare to do it who are convinced about having the truth on their side. This very feature of the curse and the cursing mass, although they are devices for revenge, makes them effective means of control against unrestrained and unjust vengeance.

Since cursing masses are basically seen as divinely justified acts, the existence of bewitchment narratives told from the aspect of the "bewitcher" should be possible - as it is the case in Csík. This means that there are people who really induce bewitchment on someone and openly admit it, whereas in suspicion-/accusation-centred witchcraft bewitching is always attributed. ${ }^{6}$ In the Valley, however, - thanks to the massive Catholic propaganda - the moral 
judgement of the cursing mass is highly ambivalent. When asked about it, people carefully express their disapproval, saying that to wish bad luck to anybody is against Christian morals, no matter how well they have deserved it. On the other hand, they strongly believe that, either in this world or after death, God will avenge every injustice - the sooner he does so, the better. Although bewitchment narratives told from the perspective of the bewitcher are practically non-existent, those stories that deal with this topic justify the application of the cursing mass in a latent manner. In such texts the conflict underlying the bewitchment is related in a detailed manner, there is no doubt considering the guilt of the bewitched party, and disapproval against the proceedings is never really stressed - if present at all.

The threat posed by the curse and the cursing masses operate as an effective social control in the community. It does not only discourage people from violating communal norms, but the news about the plaintiff visiting the Orthodox priest may convince the offender to seek reconciliation. There are narratives about thieves bringing the stolen goods back, or aggressors asking for forgiveness. As suitable explanations for misfortunes, the curse and the curse mass is used in a somewhat limited way. As a consequence of the strong belief that it only exercises its power on the wicked, nobody employs it as an explanation for their own misfortune: it would sound as pleading oneself guilty or unjust (if misfortune is the result of erroneously cursing someone). On the other hand, however, it serves as a perfect and much used explanation for the mishap of others.

The other ways in which magical harm is supposed to be done form an ideological system, antagonistic in every respect to the underlying ideology of the curse and the cursing mass. In this system, bewitchment is thought to be carried out by magical specialist called the fermekások, ${ }^{7}$ or "private" witches, who are referred to by the same expression as their professional counterparts. Most people with the reputation of being a private witch are accused of bewitching cows so that their milk goes to them or are suspected to make love magic. On the grounds of the narratives, the ratio of the professional or private witches as alleged sources of bewitchment can not be determined. Writing about Felcsík, Éva Pócs has defined the prevalent involvement of professionals as a characteristic feature of the local system (Pócs 2002: 239), ${ }^{8}$ but my data suggest that in the Valley, private witches are more frequently brought into the picture than in the communities studied by her.

As opposed to the religious specialist of the cursing mass, the fermekások, much like the witches of the persecutions are thought to obtain their power from evil transcendental forces, and the harm triggered by them affects the guilty and the innocent alike. Thus, compared to the just institution of the 
curse and the cursing mass, this diabolic type of bewitchment is seen as the manifestation of unlimited ill-will and wickedness. The bewitchment techniques applied by the witches were known all over Europe: they are believed to exercise their power by putting objects conveying bewitchment into the territory of the victims, by feeding them with magically treated food, by manipulating the victim's bodily accessories, personal belongings or photographs, or by spells.

As in the case of classical witchcraft narratives, stories about bewitchment through witches are told from the perspective of the bewitched. The dynamics of witchcraft cases belonging to this category correspond to the characteristics of the suspicion-/accusation-centred, Western and Central European witchcraft model, with the difference that in a large number of cases, accusing a wellidentified witch is missing. In such cases bewitchment is attributed - at least on a linguistic level - to an impersonal ill-will or envy that nevertheless originates in the community; only the actual bewitcher is not named or identified. What is therefore important here is not so much the transforming of a problem to an existing social conflict, but assuming that trouble fell upon the victim irrespective of his or her conduct or qualities. The supposition that it affects the innocent as well makes bewitchment by a witch the only acceptable explanation for the bewitched themselves.

So what we have is a two-sided conceptual framework, where bewitchment is supposed to be done either through a divine sphere by employing God's power or through a diabolic one by unleashing evil forces. Since the symptoms interpreted bewitchment are identical in case of both types, every misfortune has at least three potential interpretations, which assign variable roles for the bewitched: in case of harm done by a witch they are seen as innocent victims, while in case of a priestly curse they are either positioned as being guilty in the conflict leading to bewitchment, or they are believed to cause their own miseries by falsely cursing someone else. To make the scenario more complicated, people also believe that almost every type of bewitchment could be transferred from one person to another, which makes the number of possible interpretations practically unlimited. All this makes the local theory of bewitchment extremely flexible, thus offering a considerable room for negotiating the social relations of the parties involved.

\section{THE BEWITCHED}

At the time of my visit, the bewitched family belonged to those (numerous) families whose economic and financial state was remarkably weakened in the last few years. As a result of the political changes and the economic restructur- 
ing in Romania after the revolution, the head of the family - as many of his covillagers - became unemployed after working for 17 years in the nearby city. After losing his job, he tried to find employment in the village, without longlasting success. Partly as a result of this he became a chronic alcoholic with periods of serious depression. His illness put manifold burden on the family. On the one hand, his periodical inability to perform his duties on the family farm caused considerable difficulties in maintaining the homestead, where the workforce of a man is badly needed, especially in those works that provide the only monetary income of the family. On the other hand, his dissocial attitude seriously poisoned family atmosphere.

In the eyes of the community, alcohol addiction is not considered an illness, and those who got medical treatment for their drinking problems are seen as mentally retarded. In such circumstances, bewitchment is the only fully acceptable explanation for both the long-lasting lack of economic success and for the disease of the husband. Beside these problems the chronic respiratory illness of the husband's late mother was also thought to have been caused by witcheraft. Since in the studied community, in most cases, the basic economic unit is the nuclear family, ${ }^{9}$ the grandmother did not belong to the family in a strict sense. Her assumed bewitchment, however, was still believed to have an effect on the younger couple, because they shared the same courtyard.

\section{FORMATION OF THE NARRATIVE}

The construction of the family's witchcraft discourse has continued for several years, with several unwitchers taking part in it. Therefore, part of the process could only be reconstructed from repeated interviews made with the couple in the timespan of two years. The first time the wife shared their narrative with me was nearly eight years after bewitchment entered their lives. This occurred just after a serious crisis of the husband caused by a conflict with his workmates. The narrative centred on this conflict and the consequent depression of the husband, and the long history of their bewitchment was given as the reason for their intense emotional reaction to the events: they considered the crisis as the possible fulfilment of the bewitchment. Weeks later we also touched upon the topic in the presence of the husband, who admitted being bewitched but only talked about his symptoms and did not enter into any details regarding the origins and types of the magical attacks, nor did he mention his rupture with his workmates. I was lucky enough, however, to have a closer look at a later phase of narrative formation, since, when the husband's state got worse again, I was allowed to accompany the wife to a witch-doctor. Al- 
though on the request of the specialist I was not allowed to take part in their session, I had the opportunity to follow, or, due to the unintended effect of my questions, I should better say, to take part in the interpretational activity performed by the wife of the bewitched right from the beginning.

The unwitchers consulted by the villagers represent a wide spectrum of specialists, ranging from official church representatives to soothsayers. Some of them function only as a diagnostic or a healer, but most perform both roles. One of the most frequently visited specialist acting as an unwitcher is an Orthodox priest or an Orthodox monk. By performing official liturgical practices (praying, celebrating masses) or unofficial divinatory methods (bibliomantia), the priest is able to identify the source of misfortune and predict whether the bewitchment could be lifted or not. Moreover, votive masses - Orthodox and Catholic alike - are seen as the most effective protection against bewitchment, both as preventing future magical attacks, or curing the existing ones. Beside the Orthodox priests, various magical specialists are available for those who suspect bewitchment. The techniques applied by these magicians cover a wide range of divinatory practices (clairvoyance, card laying, divination by coffeegrounds), and they also offer various methods for healing. In most cases healing rituals are simultaneously performed by the unwitcher and the bewitched, although not necessarily at the same place. Recovery may need a considerable time, and repeated visits to the specialist (be it a priest or a magician) are often needed.

In the timespan of nearly eight years, the family sought the help of various witch-doctors five times. The first visit took place in the middle of the 1990s, when, after loosing his job the head of the family got so desperate that he attempted suicide. At that time his wife and his mother took his picture to an Orthodox priest in a nearby village, where they learned that he was bewitched either to end up in jail, you know, or to hang himself. The narrative is not clear on the motive and the identity of the witch. At the time of our conversation the wife mentioned envy as the reason for bewitching, and added that bewitchment was given to her husband in a glass of drink back in the time he was still unmarried. At another occasion, however, she mentioned love magic as the type of bewitchment, and the inconsistency of the narrative suggests that two independent diagnoses might have been mingled during the course of interpretation. During the visit to the Orthodox priest, the bewitchment of the husband's mother was thematised as well, and a connection between her and the husband's troubles was also made: I may have inherited it from my mother, as he said. The mother had long been aware of being bewitched through an object being hidden under the living room, which was formerly occupied by the parents of the husband, but at the time of my stay it had long been used by the 
younger couple. For this magical attack the mother accused her sister-in-law with whom, being neighbours, they had fierce fights over the property. Besides this, another explanation for the mother's illness had long been well known in the family tradition. There is a legend dating back many generations about a great-great-great-grandmother, who found a chest of money that was hidden by bandits on the family lot. ${ }^{10}$ Unfortunately, the treasure was cursed, which the incautious ancestors did not bear in mind and thus failed to use the money in a proper way - that is, to offer it for charitable purposes. As a consequence of this, all women living on the lot were believed to suffer from poor health. This belief, even if it statistically contradicted the truth, held itself so strongly in the family tradition that at certain occasions the problems of the husband were also ascribed to this ancient curse. Both the mother and the husband complained that every time they entered their courtyard, they felt as though they were going into a dark prison and that they get depressed in this courtyard. This, according to the family's interpretation, proved that the bewitchment was somehow connected to the family lot. At the time of the first visit to the priest the women were also told that since these bewitchments were made years ago, none of them could be cured, but masses said for the health of the bewitched should help from time to time.

After learning the diagnosis made at the first visit, the bewitched man and his father went to see a Gypsy cunning woman, but she did not succeed in healing him. For this they had two possible explanations: the bewitchment was indeed beyond recovery, or the unwitcher was a charlatan.

After these consecutive visits the family called in a witch-doctor only eight years later. ${ }^{11}$ At this time a neighbour took them to an Orthodox priest because the head of the family, after being rather rudely ridiculed by his mates, got into a state of depression, which was almost as critical as on the first occasion. Although this time bewitchment was not "officially" mentioned, the event was quickly integrated to the bewitchment narrative of the family, for they interpreted it as a conflict which would easily lead to the fulfilment of their bewitchment, that is, the husband would commit suicide or get into a fight which would lead to his imprisonment. As in the first case, malevolence was outdone by repeated masses paid to the Orthodox Church.

The last time the family turned to an unwitcher was more than six months after their former visit, when troubles were getting more intense again. This time a neighbour and a close friend went to visit an Orthodox priest because of her own troubles, and she agreed to make inquiry on behalf of the studied family. Again they were told that they were victims of a malevolent magical attack. Following the priestly advice, the wife soon visited a witch-doctor, recommended by one of her sister-in-laws. As a result of this visit, a somewhat 
incoherent conglomerate of several new bewitchments became to be known. According to the wife's report immediately after the session, their trouble was partly due to a bewitchment or priestly curse or a bewitchment by a witch, originally given for one of the temporary employers of the husband, but somehow also exerting an effect on him as well. A second bewitchment was also at work, which aimed to cause the death of a man or a woman - that is, the husband or the wife - and was operated through the manipulation of an object possibly stolen from the house at the funeral of a family member. In addition to this, the unwitcher told them that there is a bewitched object hidden in one of the pillows used by the couple (this was not found, however). Just as in the previous cases, no particular witch was named, although the wife had made several attempts to identify one of her neighbours as being responsible for the attacks. To eliminate the bewitchment, the unwitcher launched a complex counter-attack: she lit a holy candle and prayed for the bewitched man during the night, while ordering the wife to simultaneously carry out certain prophylactic rites over all the thresholds, pillows and family members at home. She also prescribed that, as a preventive action against the renewed attack of the witch, the family members had to put a small amount of salt into their left shoe every time they left home. The unwitcher predicted that after these rites had been carried out, a snake or a toad would appear in the courtyard, at which event the family had to turn to her again. Since none of the said animals showed up, the wife called in the witch-doctor only three months later, after things got desperate again. This time the unwitcher told them that it was too late to successfully lift the bewitchment, but she tried to give some help by performing the rites she did three months earlier. At the same time, the wife paid masses to an Orthodox and to a Catholic priest in order to gain some even if temporary - protection against the magical attack.

After the troubled year of 2004, 2005 had brought a slight improvement regarding the husband's depression. The family firmly believes that this is the result of the votive masses for family health and luck, regularly paid to both the Orthodox and the Catholic priest.

\section{CHARACTERISTICS OF THE NARRATIVE}

Legitimate witchcraft narratives are constructed by the joint effort of the witchdoctor and the bewitched, and, after their session, by the bewitched and their environment. Having been subject to a session myself about my "own bewitchment", I had a glimpse of the communicational strategies applied by the witchdoctor during the session. The process is highly interactive: the unwitcher 
covertly interrogates the patient for background information about their possible conflicts, social and kinship relations, and much in accordance with what she has learnt, offers several different bewitchment attacks as possibilities. The picture she gives is a highly incoherent one, consisting of numerous independent probabilities, and she presents this so quickly that it is impossible to follow her or to memorise what she has said: some things keep lingering on one's mind while others fall out almost immediately. So the actual interpretation must be made by the bewitched. What they have learned from the unwitcher helps them as a rather fluid guideline; they try to stick to it, but at the end, by leaving out certain things and introducing others they come up with a rather different version - which is nevertheless the most acceptable one. This work of interpretation goes well beyond the time of the session and is done partly individually and partly in conversations about the case.

In this particular bewitchment case I heard the narrative at least twice after the session: for the first time we spoke lengthily about it on our way home, and for the second time, the next day after the wife had discussed it with her husband. The two versions show considerable differences. In our first conversation, the wife mentioned the priestly curse several times, in the second she referred to it as something that was meant for another family - here it should be remembered that suffering from priestly curse proves the bewitched guilty. As for the curse on the family lot, she also refused the option of the priestly curse, and returned to the family legend about the cursed money found in the courtyard generations ago. In addition, the husband also supposed that the bewitchment might have been transmitted from his late brother-inlaw, whose sudden death was also considered to be the result of a magical attack. The couple assumed that if this was true, magical harm was conveyed to their household with the clothes and instruments they inherited from this brother-in-law. It is clear then that in the course of interpretation the couple made an effort to distance the bewitchment: only one version of the accepted bewitchment types was believed to be meant directly for them (the one given for the death of either the wife or the husband), while the others effected the family only indirectly and were thought to be originally aimed at others - the mother, the brother-in-law, or the employer of the husband. By depicting most of the attacks as independent from them, the family has constructed a more preferable self-image, which represents them as peaceful, cooperative members of the community, who are not involved in fierce conflicts leading to bewitchment.

Even the attack that they accepted as being originally aimed at them was free of open conflict, since it was believed to be motivated by envy, which they assigned to a general subject. As many anthropologists and historians study- 
ing witchcraft have pointed out, most cultures identify envy as the basic drive for bewitchment (Briggs 1996: 166; Blécourt 1999: 206-208). People in the studied village have an image of their community as being envious and ill-willed, for which witchcraft is but one symptom. ${ }^{12}$ Being a mountain valley at a relatively high altitude, the area has always been poor in resources, where, especially after the nearby cities have ceased to offer working facilities, the possibility to improve one's economic facilities has become excessively limited. As in societies where egalitarianism is latently considered as something ideal, especially those families who have managed to make some economic progress in the last decade (by establishing themselves in the local service sector or by opening their private sawmills) provide a good target for envy. Although the studied family does not belong to this category now, they considered themselves as being economically successful while the husband was working in the city, thus providing a good object for bewitchment:

In those times, you know, he was working in the city, and we made such progress, we only did not buy those things we did not want to, you know, clothes and everything, and we extended the house, and we bought a refrigerator, and everything, you know. And then they very much envied us.

Apart from this, psychologically, envy is, from the perspective of the bewitched, the most acceptable motive for witchcraft, since it suggests that they are attacked for the very cause of being perfect according to community norm, that is, to be hardworking and making economic development. In this respect the studied community to a certain extent contradicts George M. Foster's (1965) idea of 'limited good', for the perception of economic advancement is rather ambiguous in the community. On the one hand, the notion of making progress at the cost of others is an existing idea, and is best expressed in beliefs about drying-up cows. On the other hand, however, augmenting one's fortune means that one is industrious and uses his money reasonably, which, in the eyes of the community are highly respected values (although this does not mean that prospering families are not, indeed, envied by others). Thus, by establishing the family's bewitchment as motivated by (an impersonated) envy, or something that had affected them indirectly, the constructed narrative has eliminated every ambiguity considering the position of the bewitched in the events, and depicted them as being in no way responsible for what happened to them.

Another important characteristic of the narrative is its accumulative nature - that is, it integrates nearly all bewitchments diagnosed in the known history of the family. The individual symptoms are not assigned to particular bewitchment acts: the narrative works as an 'archive' from which the most 
convenient version could be assigned to the current problems. To explain the present state of affairs, a number of magical attacks directly or indirectly associated with the family were taken as possible origins of their troubles. This also implicates that in the case of this family, the state of bewitchment and not the particular bewitchment attacks were essential.

\section{THE POWER OF THE NARRATIVE}

Since the unwitching methods offered by the different witch-doctors have not convincingly put an end to the family's troubles, the narrative is open-ended and falls into a category called unfinished bewitchment narratives by J. FavretSaada (1989: 44). Despite the failure of the healing process though, the bewitchment narrative has important psychological and social effects working both within and outside the family. Being diagnosed as bewitched fundamentally changes one's relationship to the outside world. First of all, as J. FavretSaada has already pointed out in her article about the process of unwitching in contemporary French witchcraft (Favret-Saada 1989: 46), the diagnosis of bewitchment changes the role of the victims from passive to active, and by offering traditional ways of magical counter-attack, it gives them hope to solve their problems. The status of being bewitched changes the victim's position within the family as well: in the studied case, after the diagnosis the husband was classified as a victim instead of being a dissocial person, and as such, was no longer held responsible for his acts. Projection of the real source of conflict beyond family borders had reunited the couple, who, now being allies, fought against the outside threat cooperatively. As a consequence, the atmosphere had also improved in the family: no longer blaming the husband, the family members treated him more patiently, while he, in turn, sensing their affection, behaved less aggressively. Naturally, this benign therapeutic effect of the bewitchment diagnosis lasted only for a limited period, after which emotions got loose again and the diagnosis had to be reaffirmed. This did not necessarily mean calling in a witch-doctor: when discussing the gloomy state of affairs with confidants, it was enough to bring up bewitchment as the only possible explanation for the husband's behaviour to make the family more tolerant again.

Secondly, a bewitchment narrative that constitutes the bewitched as innocent victim's acts as an explanation towards the community as well, and as such, might favourably alter their position in the community. It has been stated in a number of anthropological surveys that people in liminal periods, be it a wedding, women in childbed, or heirs taking over the homestead after their 
parents' death, are believed to be especially threatened by magical attacks (Blécourt 1999: 208). ${ }^{13}$ In such periods witchcraft discourse might help to redefine the social position of the bewitched, and to determine his relationship with other community members. Although technically speaking, the husband in this case was not subject to any rites of passage, his position in the community has been somewhat shaken. Prior to loosing his job he counted to be a respected member of the community: he had a learned profession, he had a good job, and had been working abroad as a guest worker. After becoming unemployed, however, he was unable to find himself a permanent new job or establish himself as a head of a prosperous homestead, and gradually developed a reputation as a heavy drinker. Consuming alcohol regularly - even in large quantities - is seen as somewhat natural or even virile in the community, but those people who are incapable of managing their farms or are rude to their family members because of their drinking habits, meet the heavy disapproval of the public. Thus, in order to preserve the prestige of the husband, and, to a certain extent, of the whole family, the introduction of bewitchment as an explanation was necessary. The upcoming narrative offered an alternative view of his state, and by putting him in the position of the victim, applied for the sympathy and tolerance of the community - that is, to a certain extent it aimed to redefine his position.

Although the bewitchment cases are highly confidential, almost all families make their bewitchment narratives public within a certain circle. In this particular case, neighbours and relatives were repeatedly consulted, and, as it was already mentioned, some of them even took an active role in the process of unwitching. It is very important, however, to guarantee that the disseminated narrative is a version that assigns a preferable position for the bewitched, thus every family involved in such affairs try to control the formation of the discourse as much as they can. Visiting the unwitchers and carrying out the rites of counter-magic by rule has to be made in secret. The reason for this is manifold. First there is the belief that witches can renew their bewitchment if they learn that it has been eliminated by the unwitcher, or they can hinder him in his cures. And the second reason is that visiting any specialist of magic, even if it is an Orthodox priest, raises the suspicion that one wants to harm someone, either to mete out justice or to act from sheer malice. As we have already seen, although the two types of bewitchment do not fall under the same judgement, both are condemned from the perspective of Christian morals. If, however, the bewitched manage to keep their unwitching efforts and the construction of their bewitchment narrative within the circle of their confidants, there is a good chance that with their help, a version favourable to the bewitched is disseminated. 
Obviously, the bewitchment narrative as an explanation for mishap would not be homogeneously accepted by the whole community for various reasons: it would not reach everybody, there would be people who would doubt its validity and there would be parties whose concern would lie in its denial - either because they are represented in it as the enemy, or because their interests require so. What is important to the bewitched, however, is to convince those few, more distant family members, neighbours and other allies, with whom they are engaged in different kinds of exchange relationships. Maintaining these relationships is of primary concern for the family, since, due to the local conditions of agriculture, all families depend on the workforce of others in carrying out the most important work phases. To solve this problem the institution of regulated labour exchange was developed, in which one is supposed to give back the same amount of help as he gets. I believe that the bewitchment narrative indirectly helps to keep the family within this relationship, by making the partners permissive with the husband's occasional lapses in exchanges, and also, by promising to put an end to this situation.

Although I argue that bewitchment narratives are effective communicative means, I am not stating that they are explicitly and consciously used as 'propaganda devices'. The bewitched's relationship to their bewitchment narrative is more complicated than that. The narrative works only if the bewitched genuinely believe in its immanent reality, as a consequence of which they cannot regard it as something constructed to reach a certain well-defined end. For them, the subservience of the interpretational process that an uninvolved observer might easily point out is non-existent: the construction of the narrative is guided by the simple rule that they unconsciously cannot believe, and thus accept elements which show them in an unfavourable position. But, when speaking about gossip, people in the Valley use expressions like starting a talk or eating one's honour (by disseminating embarrassing news, actual or invented), which imply a certain amount of intentionality and shows that they are fully aware of the power narratives have. Thus, consciously or unconsciously used, bewitchment narratives also serve as effective means in negotiating social relations, beside, of course, providing 'inner' explanations for misfortunes. By offering a favourable image of someone, they can increase or save one's prestige, or, on the contrary, they might be used for ruining one's reputation. To put it metaphorically, they function as weapons on the battlefield for prestige. 


\section{COMMENTS}

${ }^{1}$ In her work she explains in great detail why it was impossible to gather information from both sides.

${ }^{2}$ In 2003 , I spent seven months in this village and made shorter visits - amounting to a month - in the following years.

${ }^{3}$ For a short summary on this topic see Blécourt 1999: 188-192.

${ }^{4}$ Among the most prominent works written on Western European suspicion-/accusation-centred witchcraft are Macfarlane 1970, Thomas 1971, Henningsen 1988, Briggs 1996.

5 There are good reasons to believe that this is the case in other parts of Romania as well. On the role of the Orthodox priest in other Transylvanian communities see Czégényi 1999 and Keszeg 1999.

${ }^{6}$ If we strictly follow E. E. Evans-Prichard's definition of witchcraft (Evans-Pritchard 1976), this means - as Eva Pócs has noted - that we are actually dealing with sorcery instead of witchcraft (Pócs 2002: 241).

7 The expression fermekás derives from the Romanian term for sorcerer, sorceress: fermecăt/or, -oare.

8 The existence of bewitching by a hired specialist are also confirmed in certain Hungarian witch-trials - for example in the trials conducted in the city of Sopron, in 1528 and 1529 (Németh 2005: 26). It is still questionable how dominant these cases were compared to the accusation of private witches.

9 Meaning a married couple and their unmarried children.

${ }^{10}$ Legends about dangerous bandits, who had their headquarters in the area, form a prominent part of the community's folklore repertoire.

${ }^{11}$ I became familiar with the narrative shortly after this visit.

${ }^{12}$ Another very important manifestation of malice is gossip, with which, being the most effective means for manipulating someone's reputation, witchcraft is intrinsically interwoven.

13 The examples Willem de Blécourt cites are Campbell 1964: 62; Vuorela 1967: 19; Dionisopoulos-Mass 1976: 44; Favret-Saada 1980: 137.

\section{REFERENCES}

Blécourt, Willem de 1999. The Witch, Her Victim, the Unwitcher and the Researcher: The Continued Existence of Traditional Witchcraft. In: Stuart Clark \& Bengt Ankarloo (eds.). Witchcraft and Magic in Europe, Vol. 6: The Twentieth Century. London: The Atlone Press, pp. 141-219. 
Briggs, Robin 1996. Witches and Neighbors: The Social and Cultural Context of European Witchcraft. New York: Viking.

Campbell, John Kennedy 1964. Honour, Family and Patronage: A Study of Institutions and Moral Values in a Greek Mountain Community. Oxford: Clarendon Press.

Czégényi, Dóra 1999. Magyar-román interetnikus kapcsolatok vallási vetülete. A román pap alalkja egy erdélyi közösség hiedelemrendszerében (Religious projection of Hungarian-Romanian interethnic relations. The figure of a Romanian priest in the belief system of a Transilvanian community). In: Éva Borbély \& Dóra Czégényi (eds.). Változó társadalom. Kriza könyvek, 1 (The Changing Society. Kriza Books 1). Kolozsvár: Kriza János Néprajzi Társaság, pp. 29-43.

Dionisopoulos-Mass, Regina 1976. The Evil Eye and the Bewitchment in a Peasant Village. In: Clarence Malone (ed.). The Evil Eye. New York: Columbia University Press, pp. $42-62$.

Evans-Pritchard, Edward Evan 1976. Witchcraft, Oracles, and Magic among the Azande. Oxford: Clarendon Press.

Favret-Saada, Jeanne 1980. Deadly Words. Witchcraft in the Bocage. Cambridge \& Paris: Cambridge University Press.

Favret-Saada, Jeanne 1989. Unbewitching as Therapy. American Ethnologist, 16: 1, pp. $40-57$.

Foster, George M. 1965. Peasant Society and the Image of Limited Good. American Anthropologist, 67, pp. 293-315.

Henningsen, Gustav 1988. A boszorkányok ügyvédje: A baszk boszorkányság és a spanyol inkvizíció (1609-1614). (Witches' advocate: Basque witchcraft and Spanish Inquisition (1609-1614)). Budapest: Kossuth Könyvkiadó.

Keszeg, Vilmos 1999. Mezőségi hiedelmek. (Mezőségi beliefs). Kriza János Néprajzí Társaság Könyvtára (Library of János Kriza Ethnographical Society). Marosvársárhely: Mentor K.

Macfarlane, Alan D. J. 1970. Witchcraft in Tudor and Stuart England: A Regional and Comparative Study. London: Routledge \& Kegan Paul.

Németh, Ildikó 2005. Boszorkányperek Sopronban (Witch trials in Sopron). Rubicon, 7, p. 26.

Pócs, Éva 2001. Átok, rontás, divináció: Boszorkányság a vallás és mágia határán (Cursing, bewitching, divination: Witchraft on the borderline of religion and magic). In: Éva Pócs (ed.). Két csíki falu néphite a századvégen. Örökség, 2 (Beliefs of two Csík villages at the end of century. Heritage 2). Budapest: Európai Folklór Intézet \& Osiris, pp. 435-470.

Pócs, Éva 2002. Boszorkányság a vallás és mágia határán (Witchcraft on the borderline of religion and magic). In: Éva Pócs. Magyar néphit Közép-és Kelet-Európa határán. Válogatott tanulmányok I (Hungarian beliefs on the border of Central and Eastern Europe. Selected works I). Budapest: L'Harmattan, pp. 239-264.

Thomas, Keith 1971. Religion and the Decline of Magic: Studies in Popular Beliefs in Sixteenth and Seventeenth Century England. London: Weidenfeld and Nicolson.

Vuorela, Toivo 1967. Der böse Blick im Lichte der finnischen Überlieferung. Folklore Fellows' Communications, 201. Helsinki: Suomalainen Tiedeakatemia. 